\title{
Organizational Commitment and Turnover Intention of Hotel Employees at Melawai Hotel in Jakarta
}

\author{
Purwanti Dyah Pramanik, Robiatul Adawiyah, Filma Festivalia \\ Hotel \\ Trisakti Institute of Tourism \\ Jakarta, Indonesia \\ purwanti@stptrisakti.ac.id
}

\begin{abstract}
Hotel industry was known as a company with a very high turnover intention (Boella, 2013,p.167). High employee turnover could lead to the emergence of various problems, such as shortage of employees, expenditures for recruitment fees, the cost of training new employees, inefficiency, and productivity (Uludag, 2011,p.1). Factors causing employee turnover was increasing the intention to move to another hotel. It was called turnover intention. The increasing of turnover intention was going to be affected by organizational commitment (O'Fallon, 2011,p.451). Organizational commitment consists of value commitment, effort commitment, and retention commitment (Lee, 2012,p.869-870). This study aimed to analyse the influence of organizational commitment to employee turnover intention at Melawai hotel in Jakarta. The organizational commitment included value commitment, effort commitment, and retention commitment.
\end{abstract}

The research used descriptive methods, cross-sectional, data collection techniques by distributing questionnaires, and interview. Descriptive method, the research analysed the relationship between variables. Cross sectional because it's only held in April 2015 up to April 2016. The questionnaires were distributed to 80 (eighty) employees of Melawai hotel in Jakarta. Questionnaire was divided into two parts. The first part consisted of respondent profiles. It included age, gender, status, length of work, division and job position. The second questionnaires were about organizational commitment (independent variable) and turnover intention (dependent variable). The questionnaires measured organizational commitment was found by Porter at al. (1974). It used Likert scale 4 points, the point of 1 was for strongly disagree and the point of 4 was for strongly agree. Data analysis method was validity and reliability test, descriptive analysis, Pearson correlation and simple linear regression, used SPSS 20 for windows (Santoso, 2014,p.163-380). Sampling used accidental sampling method. The employees filled in the questionnaires from the level of operational staff up to managerial level (supervisor and manager). Interview has been completed for probing information deeply. The research was in Melawai hotel.

The study concluded that turnover intention was affected negatively associated by value commitment, effort commitment, and retention commitment. In other words, the organizational commitment was negatively associated with turnover intention. The study found that value commitment, effort commitment, and organizational commitment were associated with turnover intention significantly. But retention commitment wasn't associated significantly to turnover intention.
Keywords-Organizational commitment, turnover intention, employee, and hotel.

\section{INTRODUCTION}

Every business owner wants his business to grow and develop (Enz, 2010,p.208). Those would lead additional benefits for business owners. In order to reach that aim, the organization must have a competitive advantage. Having competitive advantage was an opportunity for the company to survive and even won the competition (Blair, 2015,p.261). The most important aspect to be the winner in the competition was the human resources dimension, namely the employee. Moreover, the hotel industry was labour intensive (Kim et al., 2011,p.1). In the hotel industry, employees play an important role in the process of service to guests. That's why the availability of the appropriate hotel employees is very important.

Ironically, turnover was a problem that often occurs in the hotel (O'Fallon, 2011,p.453). The hotel industry was known as a company with a very high turnover intention (Boella, 2013,p.8). Compared with other types of businesses such as manufacturing enterprises, turnover in hotel industry was the highest (Chon, 2010,p.166). The high level of turnover at a hotel resulted in increasing inefficiencies and declining productivity (Uludag, 2011,p.1). Inefficiency increased due to the cost of recruitment and training costs for new employees. Turnover costs in 33 hotels of USD 10,000 for the difficult job categories. Productivity declined because the company lost employees while new employees were still in the learning phase. Productivity decreased by about $75 \%$ at some positions and an average of $50 \%$ off for all positions. Besides service-based knowledge that was lost with the release of employees. Although the largest turnover intention occurs on the employee front office / front-liner employees (Enz, 2010: 208), but not necessarily happen turnover at managerial level.

Hotel Melawai is a three-star hotel. It's located in a crowded shopping centre in South Jakarta. The hotel occupancy rate was pretty good, which was an average of about $70 \%$, and assessment of the guests who had stayed was 6 or above average (based on 384 reviews versions Agoda, February 2015). This hotel was originally only consisted of one building with the number of rooms is 75 rooms. But with the development of its business, is currently developing and 
adding one more building so the current total number of rooms was 150 rooms. The hotel had about 100 permanent employees. Employee turnover occurred in the age group under 50 years.

Hotel Melawai had the potential to be a good hotel. It's considering the very strategic location in the shopping centre which is always crowded in the area of South Jakarta. There are approximately 30 per cent of employees on the verge of retirement age. When a group of employees have left the hotel due to retirement, it is expected that 70 per cent of the remaining employees stay in this hotel and do not intend to move to another hotel. Lack of employees would affect the quality of hotel services. Previous study proved that turnover intention would decrease if the organizational commitment increased.

Therefore, the aims of the research was to (1) identify the link of value commitment to turnover intention, (2) identify the link of effort commitment to turnover intention, (3) identify the link of retention commitment to turnover intention, (4) the link of organizational commitment to turnover intention of the employees at Hotel Melawai in Jakarta.

The result of the research was expected to describe the level of employees' commitment to the organization in order to understand the dominant aspect that affected employees' turnover. Next, the organization would able to improve their organizational policies.

\section{LITERATURE REVIEW}

\section{A. Organizational Commitment}

Organizational commitment is a strong identification of employees in the organization where the employee works (Porter et al, 1974; Stiffler, 2007,p.19). Organizational commitment is a form of employee loyalty to organizations that marked their desire to work in an organization and the employee to maintain its presence to become a part of the company. Thus the commitment represents two things. They are the tendency of feeling and behaviour of employees of the company (Mowday et al.,1982; Jex.2008,p.153). The commitment is a reflection of employees' identification with the goals and organization as well as the desire of employees to make an organization succeed (Uludag, 2011,p.3). It could be concluded that organizational commitment is a tendency of feeling and behaviour of employees in the company that are characterized by their efforts in order to achieve the success of individual employees and the organization itself. Organizational commitment can be grouped into three dimensions: value commitment, effort commitment, and retention commitment (Porter et al 1974; Mowday et al, 1982; Stiffler, 2007,p.19, and Lee, 2012,p.869-870). Fig.1 shows the dimensions of organizational commitment according to Porter.

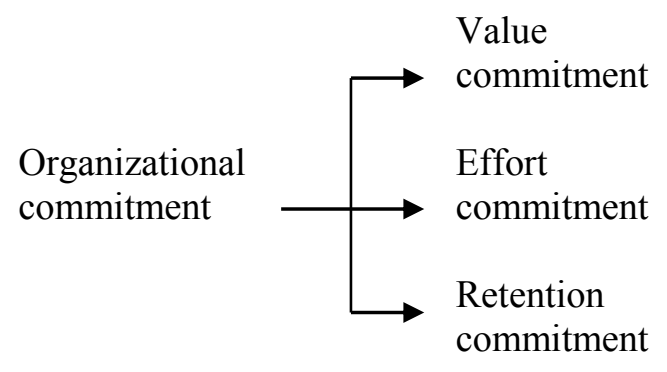

Fig.1. Dimensions of organizational commitment (Porter, 1982; Stiffler, 2007,p.19; Lee, 2012,p.869-870)

Value commitment is the confidence and acceptance of employees on goal and value. The indicator of value commitment covers their confidence and acceptance on the employee. Effort commitment is an attempt to reach the organization goals. Indicators of this dimension include trust of the employee to the organization. Retention commitment is the desire to continue working in an organization. Indicators include the empathy of employees to the organization.

Blau and Boal (1989) successfully researched that organizational commitment was able to predict employee turnover intention (Stifller, 2007,p.36). It described that organizational commitment was significantly and negatively associated with employees' turnover intention. The higher employees' commitment, there would be the lower turnover intention. Therefore, organizational commitment is an important variable that can affect turnover intention (Lee, 2012,p.866-867). The fact that organizational commitment negatively related to turnover intention is a positive thing for the organization.

\section{B. Turnover Intention}

Turnover was considered as a form of secession from the organization (Wu, 2013,p.132). Turnover intention defined as an internal perception of the possibility of an employee leaving the company (Applebaum, 2008: 59). The indicators were: (1) having strong desire to leave, (2) intending to leave the hotel, (3) searching for opportunity to work in other hotels.

Research found that lack of employees training could increase turnover intention (Tromp et al, 2010,p.118). In hotel industry, turnover intention was prevalent in front office department (Enz, 2010,p.453) and it indicated more junior employees who decided to move job than senior employees. Porter and Steers (1973) said the four main factors driving employee to move to another company (Stifller, 2007,p.32): (1) the situation in other companies, (2) working environment, (3) the job itself. But each employee had its own reason to move on. Its reasons could be: (1) other companies offer the better opportunity, (2) employees try to search for better opportunity in another company, and (3) employee has a dream to work in another company (Tromp et al., 2010,p.123). Turnover intention indicators 
were (1) having strong desire to leave, (2) intending to leave the hotel, (3) searching for opportunity to work in other hotels (Spector et al,, 1982; Lee, 2012,p.870). Based on a literature review above, the linkage of organizational commitment and turnover intention can be described as shown in fig. 2 .

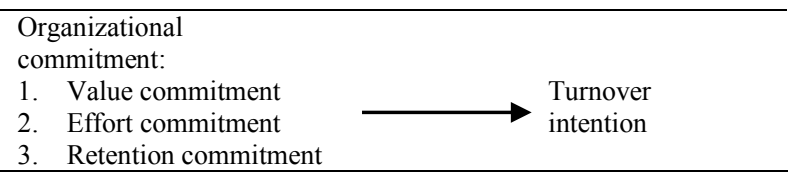

Fig. 2. The linkage between organizational commitment and turnover intention (O'Fallon et al.,2011,p.451 and Stiffler at al.,2007,p.19).

\section{Hotel}

The hotel industry is the oldest industry in the world. Hotel or Inn is a place where travellers can enjoy food, drinks and places to stay. The rating for the service must pay the appropriate facility receives (Brederode, 2011,p.59). The hotel provides lodging, food or beverages, or a combination of these service activities (Harrison, 2005,p.23). Human resources in the hotel is very important. The jobs are varies depending on the size of the hotel. Hotels might consist of departments of marketing, human resources, food and beverage, accounting and rooms. Larger hotels also have a department of engineering, public relations, and convention services. Melawai hotel is led by a general manager which is a son of the owner. It has six departments. They are department of accounting, food and beverage, housekeeping, front office, engineering, and human resources. The numbers of permanent employees are around a hundred employees. The age of the employees are from 20 up to 60 years old. The retirement ages are 55 years old.

The management implemented efficiency in its operational. For example: a human resource supervisor was responsible for all human resource activities, starting from procurement until retirement phase. That's why the activity of training is difficult to be conducted. If a person went to take training, there wouldn't any substitution employees. The framework of the linkage of organizational commitment to employee's turnover intention at Melawai hotel in Jakarta was described in fig. 3.

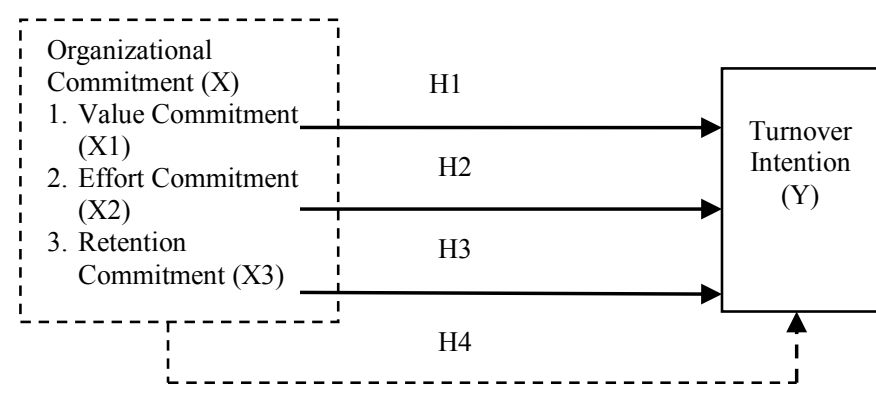

Fig. 3. The framework
H1. Value commitment is negatively associated with turnover intention.

H2. Effort commitment is negatively associated with turnover intention.

H3. Retention commitment is negatively associated with turnover intention.

H4. Organizational commitment is negatively associated with turnover intention.

\section{METHODOLOGY}

The research method was descriptive approach to obtain a full picture of the organizational commitment and turnover intention of the hotel employees who became the object of research. The time spent in cross-sectional start from April 2015 up to April 2016. Data collection techniques using a questionnaire consisting of two parts. The first part, the profile of respondents, while the second part of the variables $\mathrm{X}$ and $\mathrm{Y}$. The unit of analysis of this study is approximately 80 Melawai hotel employees in Jakarta. In this study, the sampling is accidental sampling, the sampling process is done by chance without a certain consideration.

The respondents consisted of: (1) 18 to 28 years old was 27 persons $(33.8 \%)$, (2) 29 to 39 years old was 15 persons (18.8\%), (3) 40 to 50 years old was 23 persons $(28.8 \%)$, (4) above 50 years old was 15 persons $(18.8 \%)$.

The percentage of male was 58 people $(72.5 \%)$ and female was 22 people $(27.5 \%)$. The married people was 74 people $(92.5 \%)$ and single was 6 persons $(7.5 \%)$.

Based on status: (1) married was 69 persons $(86.3 \%)$ and single was 11 persons $(13.8 \%)$.

According to the length of work: (1) 0 to 10 years was 37 persons $(46.3 \%),(2) 11$ to 21 years was 24 persons $(30 \%)$, (3) 22 to 32 years was 6 persons $(7.5 \%)$, (4) more than 32 years was 13 persons (16.3\%).

The questionnaires were filled out by employees who worked in: (1) Accounting department was 13 persons (16.3 $\%$ ), (2) Food \& beverage department was 17 persons (21.3\%), (3) Housekeeping department was 15 persons $(18.8$ $\%$ ), (4) Front office department was 14 persons (17.5\%), (5) Engineering department was 13 persons (16.3\%), (6) Security section was 7 persons $(8.8 \%)$, (7) Human resources department was 1 person (1.3\%). The levels of respondent were 4 managers $(5 \%), 4$ supervisors $(5 \%)$, and 72 persons (90\%).

\section{FINDINGS AND DISCUSSION}

The data analysis was conducted on the validity and reliability test, descriptive analysis, Pearson correlation analysis and simple linear analysis with SPSS 20 for Windows (Santoso, 2014,p.163-380).

\section{A. Validity and Reliability Tests}

Validity test which correlation was significant at the .01 level (2-tailed) showed that the items value were .645 to .840. They were higher than r-table (.2199). So that all questions were valid. 
Reliability test which was used Cronbah's alpha for all questions (18) was .813. $\mathrm{r}$ table for $\mathrm{N}=80$ persons at significantly $5 \%$ was .2199 . Alpha $=.813>\mathrm{r}$ table $=.2199$. It meant that all questions were reliable.

\section{B. Descriptive Analaysis}

Descriptive statistics was showed in table 1.

\begin{tabular}{lll}
\hline & The lowest mean & The highest mean \\
\hline $\begin{array}{l}\text { Organizational } \\
\text { commitment (X): }\end{array}$ & 3.28 & \\
$\begin{array}{l}\text { 1. Value } \\
\text { commitment(X1) }\end{array}$ & 3.18 & 3.46 \\
$\begin{array}{l}\text { 2. Effort } \\
\quad \text { commitment(X2) }\end{array}$ & 3.09 & 3.31 \\
$\begin{array}{l}\text { 3. Retention } \\
\text { commitment(X3) }\end{array}$ & 3.46 \\
Turnover intention (Y) & 1.81 & 1.99 \\
\hline
\end{tabular}

The lowest mean of value commitment was 3.28. It was for the statement of "I had the similar values to the hotel values". It meant that the employee had the similar values to the hotel values. This condition described the employees' acceptance to the hotel values. The highest mean of value commitment was 3.46. It described value commitment for the statement of "I'm proud if people mention about the hotel". This value also described retention commitment for the statement of "Do the best for the hotel." The lowest mean of effort commitment was 3.18. It was for the statement of "I'm staying in this hotel". The statement described that the employees agreed to work in the hotel. The highest mean of effort commitment was 3.31. It was for the statement of "work in the hotel was the right choice." It described that the employees agreed to work in the hotel. The lowest mean of retention commitment was 3.09. It's for the statement of "I was worried of the guest complaint". The situation implied the employees' empathy. The highest mean of retention commitment was 3.46. It was for the statement of "I supported the hotel to reach success". It meant that the employees agreed they were supporting the hotel to reach success. The lowest mean of turnover intention was 1.68. It's for the statement of "I intended to leave the hotel". It described that "employees disagreed of leaving the hotel". The highest mean was 1.99. It's for the statement of "I searched for another opportunity in another hotel". It implied that the employees disagreed to search for working opportunity in another hotel.

\section{Pearson Correlation Analysis}

Pearson correlation was described in table 2 .
Table 2

Pearson correlation

\begin{tabular}{cl}
\hline Sub variable/variable & Turnover intention \\
\hline Value commitment & $-.509^{* *}$ \\
Effort commitment & $-.596^{* *}$ \\
Retention commitment & $-.322^{* *}$ \\
Organizational commitment & $-.545^{* *}$ \\
\hline **. Correlation is significant at the 0.01 level (2-tailed)
\end{tabular}

Correlation of value commitment to turnover intention was $-.509^{* *}>.5$. It meant that value commitment was strongly and negatively associated with turnover intention. If value commitment which consisted of confidence and acceptance on company goals and the organization was high, the employees' turnover intention would be low or they didn't want to leave the organization. H1 is accepted.

Correlation of effort commitment to turnover intention was $-.596^{* *}>.5$. It meant that effort commitment was strongly and negatively associated with turnover intention. If effort commitment which consisted of trust of the employee to the organization was high, the employees' turnover intention was low or they didn't intend to leave the organization. $\mathrm{H} 2$ is accepted.

Correlation of retention commitment to turnover intention was $-.322^{* *}<.5$. It meant that retention commitment negatively associated with turnover intention. This value meant that if the empathy of employees to the organization was high, the turnover intention of the employees could be low. But its correlation wasn't strong. $\mathrm{H} 3$ is accepted.

Correlation of organizational commitment consisted of value commitment, effort commitment, and retention commitment to turnover intention was $-.545^{* *}>.5$. It meant that organizational commitment of Melawai hotel employees was strongly and negatively associated with turnover intention. It could be said that if the organizational commitment was high, the employees' turnover intention would be low. H4 is accepted.

\section{Simple Linear Analysis}

Simple linear analysis was described in table 3.

Table 3

Organizational commitment to turnover intention

\begin{tabular}{|l|r|r|r|r|r|r|}
\hline & \multicolumn{2}{|c|}{$\begin{array}{c}\text { Model } \\
\text { Summary }\end{array}$} & \multicolumn{2}{c|}{ ANOVA } & \multicolumn{2}{c|}{ Coefficients } \\
\hline & $\mathbf{R}$ & $\begin{array}{c}\text { R } \\
\text { square }\end{array}$ & F & Sig. & Constant & Regression \\
\hline $\begin{array}{l}\text { Oc } \\
\text { to } \\
\text { ToI }\end{array}$ & .545 & .297 & 32.892 & .000 & 14.553 & -.183 \\
\hline
\end{tabular}

Oc $=$ Organizational commitment(consist of value commitment, effort commitment, and retention commitment), ToI=Turnover intention

Independent variable was organizational commitment and dependent variable was turnover intention. $\mathrm{R}$ value was .545 . It described that organizational commitment was strongly associated with turnover intention at hotel Melawai employees. R square was .297. It meant that organizational 
commitment contributed $29.7 \%$ to employees' turnover at Melawai hotel in Jakarta. Employees turnover at Melawai hotel in Jakarta was affected by other variables $70.3 \%$ excluded organizational commitment. Sig. Value was .000< sig. criteria (.05). It showed that regression model based on research data was significant. The linear regression model fit the criteria of linearity. $F=32.892$ with the level of significance/ probability was $.000<.05$, so that regression model could be used to predict turnover intention. Regression was $\mathrm{Y}=14.553+(-.183) \mathrm{X}$. If there wasn't the value of organizational commitment, turnover intention would be 14.553. Coefficient regression was -.183. It meant 1 point organizational commitment improvement could reduce -.183 of turnover intention.

\section{CONCLUSION AND SUGGESTION}

The study concluded that turnover intention was affected negatively associated by value commitment, effort commitment, retention commitment, and the organizational commitment (which consisted of value commitment, effort commitment, and retention commitment) was negatively associated with turnover intention as well. The study found that value commitment, effort commitment, and organizational commitment were associated with turnover intention significantly. But retention commitment wasn't associated significantly to turnover intention.

From the research, it's found some problems. Those were the regeneration of employees, training programs, and target setting. There were around -in this year- 30 (thirty) per cent of employees would be in retirement's ages. Due to the situation, it was suggested to prepare an appropriate procurement to anticipate lack of employees. Moreover, the numbers of employees were strictly limited. One employee was doing many jobs. This condition made the training program was very difficult to be conducted. Training for employees would improve the confidence to reach the target. Target setting was decided by supervisor without considering operational staff participation. Staff participation would enhance employees' commitment to reach the goal.

\section{REFERENCES}

[1] Applebaum Diane Helen, "The relationship between physical work, environmental factors, perceive.” USA: UMI, pp. 59, 2008.

[2] Blair D. Roger and Sokol D. Daniel, "The oxford handbook of international antitrust economics," Oxford University Press, New York, vol. 2, pp. 261, 2015.

[3] Boella J. Michael and Goss-Turner Steven, "Ninth edition: human resource management in the hospitality industry a guide to best practice.” Routledge: Canada, pp. 167, 2013.

[4] Brederode F.W. Robert, "Immovable property under VAT: a comparative global analysis." Kluwer Law International BV: The Netherlands, pp. 59, 2011.

[5] Chon Kye-Sung (Kaye) and Maier Thomas, "Third edition: welcome to hospitality: an introduction." Delmar Cengage Learning Inc.: New York, pp. 166, 2010.
[6] Enz A. Cathy, "Hospitality strategic management: concept and cases second edition."John Wiley \& Sons: New Jersey, pp. 208, 2010.

[7] The Cornell School of Hotel Administration: handbook of applied hospitality Strategy, Edited SAGE Publication,Inc,California, 453. 2010.

[8] Harrison S. Jeffrey and Enz A. Cathy, "Hospitality strategic management: concepts and cases." John Wiley and Sons Inc.: New Jersey, pp. 236, 2005.

[9] Jex, "Commitment in the workplace: theory, research, and application.” Thousand Oaks, CA. Sage. Reprinted by permission of Sage Publications,Inc.:CA, pp. 154, 2008.

[10] Kim Youngmi, Kim Samuel Seongseop, Seo Jeongmo, Hyun Jaechun, "Hotel employees' competencies and qualifications required according to hotel divisions," Journal of Tourism Hospitality \& Culinary Arts vol.3, Issue 2., 1-18, 2011.

[11] Lee Chun-Chang, Sheng-Hsiung Huang, and Chen- Yi Zhao, "A study on factors affecting turn over intention of hotel employees," Jurnal Asian Economic and Financial Review, vol. 2, issue 7:866-875 JEL Codes: J63, J28, M54, Taiwan, 866-875, 2012.

[12] O'Fallon J.Michael and Rutherford G. Denney, "Hotel management and operations: fifth edition.” John Wiley and Sons,Inc.: New Jersey, pp. 451-453, 2011.

[13] Santoso, Singgih, "Panduan lengkap SPSS versi 20, edisi revisi." Kompas Gramedia: Jakarta, pp. 5-331, 2014.

[14] Stiffler Kathleen R. and Ann Arbor, "Direct support staff perceptions of frontline supervisor's skills: correlation with organizational commitment and intent to leave." UMI Number: 3277701.Capella University, pp. 19-36, 2007.

[15] Tromp M. Debbie, "Turnover intentions of highly educated hospiotality employees," Journal of advances in hospitality and leisure, vol. 6, Edited by Chen S. Joseph. Emerald Group Publishing Limited,Wagon Lane, pp. 118-130, 2010.

[16] Uludağ Orhan, Sonia Khan, and Nafiya Güden, "The effects of job satisfaction, organizational commitment, organizaional citizenship behavior (OCB), on turnover intentions," Jurnal FIU Review vol. 29 No. 2 Florida International University, pp. 1-21, 2011.

[17] Wu Min, Wang Jia," Developing a charismatic leadership model for Chinese organizations: mediating role of loyalty to supervisors. Paradigms, models, and theory." Edited by Warner Malcolm. Taylor and Francis: Canada, 132, 2013. 